\title{
Deus e o Absoluto
}

\author{
God and the Absolute
}

Denis Lerrer Rosenfield ${ }^{1}$

\begin{abstract}
Resumo: A fim de responder à pergunta: "o que pode bem significar conhecer, racionalmente, o Absoluto e quais são os instrumentos de tal empreendimento?", o Autor se propõe a reexaminar a concepção de Deus e do Absoluto em Hegel e suas recepções. Trata-se de responder ainda a questões fundamentais que lhes são correlatas: Como pode a razão, unicamente com os seus meios, alçar-se a um tal empreendimento? O que significa conhecer um tipo de existência que se subtrai aos sentidos e à experiência tal como a compreendemos no sentido filosófico não metafísico?
\end{abstract}

Palavras-Chave: Absoluto, consciência, Deus, Hegel, metafísica, religião

\begin{abstract}
In order to address the question "what can it mean to know rationally the Absolute and what are the instruments for such an enterprise?", the author sets out to reexamine the conception of God and the Absolute in Hegel and its receptions. What is at issue is also dealing with the fundamental questions that are related to them: "How can reason alone, through its means, rise to such an undertaking? What does it mean to know a kind of existence that is subtracted from the senses and experience as we understand it in the non-metaphysical philosophical sense?

Keywords: Absolute, consciousness, God, Hegel, metaphysics, religion
\end{abstract}

\section{Percurso da filosofia hegeliana}

Convém, preliminarmente, ressaltar que a Ciência da Lógica, obra de Filosofia Primeira, dedica-se ao conhecimento de realidades suprasensíveis, metafísicas, para além da física, neste sentido. Publicada em 1812, é posterior à Fenomenologia do Espírito, de 1807. Não se trata, porém, de um mero antecedente temporal, mas de uma condição propriamente lógica. A Ciência da Lógica parte de um começo muito específico, a saber, o da exposição interna das categorias - ou determinações - da Fenomenologia do Espírito. Logo, não estamos diante de um começo do mundo físico, como, por exemplo, o da Física aristotélica,

\footnotetext{
${ }^{1}$ Colunista do Globo, Professor Emérito, UFRGS < denisrosenfield@globo.com>
} 
mas de um começo propriamente conceitual. Começo aqui significa o Saber do conceito por si mesmo, apresentando, em sua forma pura, as determinações que foram engendradas no percurso mesmo graças ao qual a Consciência, em suas diferentes experiências, alcançou um conhecimento de si em seu processo mesmo de constituição. Conhecendo o mundo, conheceu-se; conheceu-se a si mesma, conhecendo-se em sua formação no mundo. Alçou-se à posição do Saber absoluto, experimentando-se no mundo, dissolvendo-se e engendrando-se neste processo. Conheceu o Absoluto em diferentes experiências da consciência, em seus impasses, em seus problemas e, inclusive, nas lutas que permeiam a história mesma da humanidade. O Absoluto não lhe foi dado por um ato de crença, mas conquistado por um Saber racional. Nas palavras de Hegel: "A lógica, como a ciência do pensar puro ou, em geral, como a ciência pura, tem por elemento esta unidade do subjetivo e do objetivo que é o Saber absoluto, e à qual o espírito se elevou como à sua verdade absoluta"².

\section{Experiência da Consciência}

Se não podemos falar de experiência no sentido de experiência propriamente física, empírica ou imediata, isto não significa que Hegel não tenha presente um outro sentido da experiência, o da experiência fenomenológica ou da consciência em seus diferentes graus de efetivação de si. Trata-se de um périplo de outro tipo, o mediante o qual a consciência apropria-se de si apropriando-se do mundo. A consciência, em seu desenvolvimento, faz diferentes tipos de experiência, desde a mais imediata de sua certeza de si, confrontando-se com as coisas do mundo, até o seu conhecimento do mundo físico através das leis que o regem, passando pela luta do reconhecimento na dialética do senhor e do escavo e, posteriormente, em uma análise de tipo religioso-fenomenológica na Consciência Infeliz. E isto enquanto apenas condições para expor-se na efetividade do mundo, em que um outro tipo de experiência a faz ver e viver o mundo de outra maneira, em experiências literárias, históricas, artísticas e religiosas. E é precisamente neste percurso que a Consciência ou a Consciência de si vai fazer que se forja o seu Saber do Absoluto, talvez

\footnotetext{
${ }^{2}$ Hegel, G. W. F. Science de la logique. Tomo I. Primeira edição de 1812. Traduction, présentation et notes par Pierre-Jean Labarrière et Gwendoline Jarczik. Paris, Aubier, 1972, p. 33.
} 
sendo o Absoluto esse próprio Saber de si em uma nova interlocução da Consciência com algo que lhe abarca, mas que é imanente a seu próprio processo.

\section{Objeto}

A Consciência, ao chegar no percurso fenomenológico ao Saber absoluto enquanto seu saber de si, que é o do Espírito em seu aparecer, deve, doravante, tomar-se a sim mesma como seu próprio objeto. Contudo, não se trata de uma mera apercepção ou de uma consciência simples de si, mas a culminação de um longo processo em que ela se colocará, em seus diferentes momentos da Fenomenologia (Consciência, Consciência de si, Razão, Espírito e Saber absoluto) como a certeza racional, não sensível nem imediata, de si mesma. Nesta perspectiva, ela tomar-se-á como seu próprio objeto na medida em que a oposição entre sujeito e objeto foi "aufgehoben". O objeto e o objetivo ganham aqui uma nova significação. A nova noção de objeto portará, em seu interior, as determinações do pensar que se elaboraram e se desenvolveram no transcurso deste processo. Trata-se, portanto, de explicitar e pensar por si mesmas estas novas determinações. O objeto foi interiorizado no Saber absoluto, esta nova síntese entre o objetivo e o subjetivo. "A Lógica é a Ciência Pura, o saber puro em sua amplidão e sua extensão. O Saber puro é a certeza tendo chegado à verdade, ou a certeza que não é mais diante do objeto, mas o interiorizou, o sabe como a ela mesma, e da mesma maneira, por outro lado, abandonou o saber de si como de algo que estaria em face do que é objetivo e seria apenas a sua supressão, externou-se e é

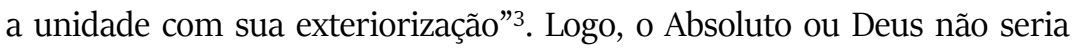
algo externo dado à Consciência, algo com o qual ela se defrontaria, mas uma síntese entre o objetivo e o subjetivo, configurando-se, se se quiser manter a nomenclatura do objeto, própria do entendimento, como um objeto de novo tipo. Deus posiciona-se como a interioridade mesma do Saber absoluto, uma síntese de novo tipo, englobante, constituindo, então, um Saber que pode ser qualificado de absoluto. O Absoluto é a interioridade mesma do Saber absoluto.

\footnotetext{
${ }^{3}$ Hegel. Ciência da Lógica. Tomo I. Prefácio a Primeira edição. Tradução de Christian Iber, Marloren Miranda e Federico Orsini. Petrópolis, Vozes, 2016, p. 28.
} 


\section{Ser no mundo}

Nas palavras mesmas de Hegel: "A consciência, enquanto o espírito que se manifesta e que, seguindo o seu caminho, liberta-se da sua imediatidade e da concreção exterior, torna-se saber puro, o qual, por sua vez, toma para si mesmo como objeto aquelas essencialidades puras tais

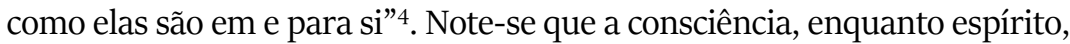
está desde sempre inscrita no mundo, devendo, neste sentido, apropriarse progressivamente de sua experiência de vida. A consciência, apenas aparentemente, defronta-se com um mundo à parte de objetos, visto que este modo de existência primeiro é o de inscrição dela mesma neste mundo, seu mundo, sendo essencialmente constitutiva dele. Ela só vem a ter uma consciência de si a partir desta sua inscrição, desta sua condição de ser no mundo, a partir da qual ela começará a depurar a sua experiência de sua imediatidade e de sua concretude, chegando, assim, a um outro nível existencial, o de seu saber de si enquanto ser no mundo, podendo, então, conhecer-se em suas essencialidades, em suas determinações lógicas. Chegará, então, a exposição do vir a ser do Absoluto enquanto conhecimento que ela conquista de si. O Absoluto depreende-se do ser-nomundo da consciência, de sua experiência imediata e concreta ao Saber absoluto de si, experiência propriamente conceitual, passando pela sua experiência histórica em suas várias configurações.

\section{Consciência religiosa}

Devemos guardar presente a importância que Hegel concede à experiência religiosa na Fenomenologia do Espírito, sendo o lugar de formação de uma consciência do Absoluto, embora sob forma representativa. Ou seja, a consciência religiosa é uma etapa necessária que conduz ao Saber absoluto, não se podendo chegar a esse sem a passagem por aquele. A consciência religiosa apropria-se do Absoluto fazendo essa experiência de si para, então, alçar-se a seu conhecimento propriamente racional. Deus é o nome do Absoluto na perspectiva da representação religiosa. A consciência representativa é uma consciência incompleta por 
não ter ainda se realizado na completude da razão. Embates entre consciências religiosas diferentes são decorrentes de elas se situarem no nível da representação, como quando diversas consciências do Absoluto arrogam-se, cada uma para si, uma centralidade divina, baseada, precisamente, na exclusão de outras. Hegelianamente, deveria haver uma consciência de si das mais diferentes consciências religiosas particulares, cada uma podendo, em seus recintos próprios, guardar suas formas específicas de culto, liturgia e rituais. Uma crença do Absoluto não pode impor-se, sob pena de o Absoluto esfacelar-se racionalmente. Cabe, contudo, aqui uma consideração suplementar. Se é bem verdade que o Absoluto deve acolher em si as mais diferentes formas de consciência religiosa, uma questão de outro tipo pode aqui ser levantada. Qual seria o lugar da irreligiosidade? Poderia um ateu alçar-se à posição do Saber absoluto, recusando-se a fazer o percurso da consciência religiosa que é uma condição mesma da razão? Haveria lugar para a irreligiosidade na filosofia de Hegel? Pode-se chegar ao Absoluto sem se fazer a experiência de sua mesma representação? Não é essa uma pressuposição do conceito que deve trabalhá-la e permeá-la?

\section{Transcendência e imanência}

Note-se que o Deus hegeliano não é o da transcendência, mas o da imanência de um Absoluto que se apresenta graças ao dizer do homem, graças ao seu Logos, não sendo possível asseverar uma existência de Deus anterior ao homem, pois isto seria equivalente a falar de um Existente sem diç̧ão, um Existente que não se manifestaria, um Existente sem Logos. Ora, é o Logos, finito, humano, que enuncia o Absoluto, que só comparece mediante esta locução, como se exigisse uma interlocução. Deus torna-se não somente imanente ao mundo, mas, mais especificamente, à sua dicção através da razão. Deus existe, em certo sentido, mediante sua enunciação racional. Ou seja, não haveria um Deus para si, cuja existência prescindiria do homem. Deus chega a si através de uma consciência que progressivamente fará o seu caminho do em si, do para si, do em e para si, até chegar ao para nós, quando, na perspectiva do Saber absoluto, ele poderá reencontrar-se plenamente enquanto Absoluto. Acontece, porém, que este reencontro não é o encontro de realidades prontas e acabadas em si, mas ele é a sua própria produção de si em seus desencontros lógicos, 
fenomenológicos e históricos. A consideração do Absoluto enquanto imanente não somente ao mundo, mas ao homem, tem como condição lógica a sua própria produção de si. Não apenas o homem chegou a si no Saber absoluto, mas também Deus que conseguiu esta dicção de si.

\section{Analogia}

Gostaria de fazer aqui uma analogia. Um teólogo judeu, Abraham Joshua Heschel, em seu livro, God in Search of Man ${ }^{5}$, coloca-se, filosoficamente, na posição de o Absoluto procurar o homem, um homem que o enuncie, acolha e aja segundo preceitos que teriam sido dados na Torá. Acontece que algo desta maneira dado, por mais importante ou sagrado que seja, deve ser constantemente vivificado, reengendrado, sob pena de tornar-se coisificado, perdendo a sua validade. Seriam os momentos descritos, por exemplo, de queda na idolatria, de perda da crença. Seria uma situação em que não apenas o homem se alienaria de Deus, mas Deus do homem. Ou seja, será que propriamente poder-se-ia falar de Deus se esse também não se buscasse, não se procurasse no homem que, por este intermédio, deve, por sua vez, buscar-se em Deus para encontrar-se ou reencontrar-se consigo? O que Heschel formula teologicamente é uma posição filosófica em que a experiência do Absoluto deve ser posta e reposta para utilizar a linguagem hegeliana, através de uma interlocução em que ambas as partes, para se enunciarem respectivamente, devem fazer a experiência da separação e da unificação, sem que se saiba ao certo que a unidade conquistada vá ou não permanecer. Também o ápice racional conquistado no Saber absoluto é nada mais do que a culminação de um longo e penoso percurso que, logo, deverá entregar-se a um recomeço.

\section{Proximidade e distância do Absoluto}

"Perto está o Eterno dos que O invocam, de todos que O chamam

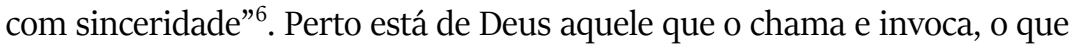

\footnotetext{
${ }^{5}$ Heschel, Abraham Joshua. God in Search of Man. New York, Farrar, Straus and Giroux, 1976.

${ }^{6}$ Bíblia Sagrada. Salmo 145 - Salmo de David. Tradução de João Ferreira de Almeida, São Paulo, Sociedade Bíblica do Brasil, 1993.
} 
significar dizer que longe Dele encontra-se todo aquele que não consegue estabelecer com Ele uma interlocução, digamos uma relação de mútuo chamamento. A palavra tem aqui a função de aproximação com Deus, de com Ele iniciar ou firmar uma relação, que obedeceria, então, a sua regras específicas, que seriam as da Torá. Ou seja, em sua ausência - na blasfêmia ou no ateísmo - haveria, pelo contrário, uma quebra de relação ou não estabelecimento de interlocução, estando a criatura abandonada ao desamparo. No interior da experiência religiosa, assim compreendida, estas regras estipulariam o que seria suscetível ou não de conhecimento, os limites da razão no uso mesmo que faz das palavras e a atitude reverencial do homem em relação a Deus, cujo eixo encontra-se em uma razão que se submete ao que lhe ultrapassa. Mais especificamente, o homem tem o temor, o medo, de ir além das barreiras desta maneira colocadas. Contudo, o que pode bem significar tal proximidade do homem com Deus se ela se dá segundo a concepção hegeliana de uma razão infinita, de que uma razão que toma barreiras para suprimi-las e elevá-las a um novo patamar de conhecimento? A razão aproxima-se de Deus não mais reconhecendo os limites impostos pela fé, pela consciência religiosa, acolhendo-O não na atitude de subordinação, mas de uma espécie de mútua determinação. O Deus da consciência religiosa, ao ser objeto deste novo tipo de acolhimento, torna-se o Absoluto de uma razão que se coloca, precisamente, enquanto absoluta, infinita. O Absoluto seria o Deus desta razão determinada.

\section{Consciência infeliz}

Na Consciência infeliz, Hegel analisa um tipo de experiência representativa - da Consciência de si, em que essa defronta-se consigo na posição de submissão na qual se coloca diante de um Transcendente que é tido por seu Senhor. Trata-se, porém, de uma experiência única, a que se indaga pela própria condição humana. Note-se que a Consciência de si coloca-se nesta posição, posiciona-se a partir de uma determinada experiência religiosa de submissão aos ditames de um Deus que se situa para além dela mesma. Infeliz, por que abre-se aqui um espaço que ela não consegue preencher, o espaço do finito submetido ao infinito, da Consciência de si submissa à Consciência de si transcendente e onipotente. Este espaço, o espaço da separação e, diria, da incognoscibilidade é aquele 
ao qual ela deverá enfrentar-se para apropriar-se de si, tornando-se Senhora de si. Ora para que consiga ser Senhora de si, ela deverá necessariamente trazer o Transcendente para a Imanência, deverá ver-se fazendo uma experiência particular que deverá ser "aufgehoben”. A separação - e o seu espaço de diferenciação absoluto - deverá ser suprimido e elevado para que, então, seja conservado em uma nova acepção de Deus enquanto Absoluto, logicamente absoluto.

\section{A essência de Deus}

Assinale-se que esta exploração racional de Deus, adentrando-se em sua interioridade, é, por sua vez, produto de um percurso filosófico que encontra em Descartes seu ponto de inflexão. Esse parte de uma Ideia inata, a de Perfeição, para conferir existência a esta mesma ideia, independentemente de qualquer realidade sensível. A ideia de perfeição existe por ser algo com que a razão defronta-se no momento em que procura conhecer - e conhecer-se -, pois seria inconcebível que faltasse a essa ideia uma perfeição como a da existência. A ideia de Deus como ser perfeito não poderia não existir na medida em que não tivesse nenhuma realidade. Reconhecer o caráter inato da Ideia da Perfeição sem a existência implicaria uma contradição lógica. De posse desta ideia, contudo, permaneceria o seu caráter transcendente, um mais além inacessível ao que seria Deus em si mesmo. A separação seria aqui radical. Ela poderia ser logicamente compatível com a tradição do "Deus absconditus" da tradição paulina e judaica, tão viva na época de Descartes segundo a tradição agostiniana e jansenista, contemporânea da Descartes. Observe-se, mesmo, a proximidade de nosso filósofo com um dos interlocutores/comentaristas das Meditações Metafísicas, na figura do grande representante de Port-Royal, Antoine Arnauld. O Cardinal de Bérulle, Núncio Apostólico e Diretor de Consciência de Descartes, era também um agostiniano. Contudo, frente a este espaço teológicofilosófico, o filósofo francês dá um passo adiante, o de explorar pela razão a essência de Deus. 


\section{A desmedida da razão}

Note-se que a razão passa a não mais reconhecer limites, não se colocando na posição de serva da fé. Poder-se-ia dizer que ela sucumbe a hyubris, à desmedida, pois o metro da fé não pode mais lhe servir como barreira. O Deus da razão tomará progressivamente o lugar do Deus da Fé. As provas da existência de Deus ganharão proeminência filosófica. Fará, então Descartes, uma distinção importante entre conhecer e compreender. Conhece-se algo pela causa que lhe dá acesso à sua razão de ser, como quando conhecendo algo por seu atributo principal. Compreender, por sua vez, nos conduz à finalidade de alguma coisa, à sua causa final. Nessa última acepção, Deus é incompreensível pois o seu "por que", a finalidade com que faz ou deixa de fazer alguma coisa - o homem e o mundo - é para nós para sempre inacessível. Temos aqui a crítica cartesiana ao conceito aristotélico de causa final. No entanto, podemos conhecer Deus pelo acesso racional a seu atributo principal, o que define a sua natureza. E esse Descartes considera como sendo o da onipotência. Deus conhece-se racionalmente pela sua onipotência. Ora, Hegel, ao retomar este percurso filosófico, ao apropriar-se dele, pergunta-se, a partir do atributo da onipotência, pelo como o Absoluto se põe em movimento, quais são suas determinações, como ele se move pelas determinações da essência, da reflexão. Um ser onipotente é um ser capaz de se colocar ele mesmo em movimento.

\section{Prova ontológica}

Já Santo Anselmo, no século XI, havia elaborada a prova que, posteriormente, tornou-se célebre enquanto prova - ou argumento ontológica7. Também ele partia de uma ideia segundo a qual Deus "é algo tal que nada maior pode ser pensado", o que significa dizer que seria contraditório dele subtrair a existência ou a realidade. Tal ideia não poderia, portanto, existir apenas no intelecto, devendo englobar necessariamente a existência ou a realidade. $\mathrm{O}$ argumento anselmiano assume o que se poderia denominar de uma perspectiva de abordagem da

\footnotetext{
7 Santo Anselmo. Proslogion. In: L'oeuvre de S. Anselme de Cantorbery. Tomo I. Introduction, traduction et notes par Mchel Corbin, s.j. Paris, Cerf, 1986. Tradução de Angelo Ricci. São Paulo, Abril/Nova Cultural, 1988.
} 
ideia cujo critério, digamos, seria de ordem essencialmente quantitativo. Aplicar-se-ia uma determinada noção da quantidade de forma a englobar o intelecto e a realidade, sem que, no entanto, a existência seja deduzida da própria ideia. Não se trataria de uma ideia que se poria em movimento, o que seria o vir a ser do Absoluto. No sentido, hegeliano, talvez se pudesse dizer que não se trataria de uma atividade da razão, mas do intelecto que se debruça, mediante o uso da categoria da quantidade, sobre uma existência determinada, previamente admitida enquanto ato de fé. Ou seja, Deus existiria à maneira de um estado de coisas dado, sendo o argumento ontológico um instrumento intelectual de explicitação de uma realidade previamente admitida enquanto existente ${ }^{8}$. Para Hegel, provar é o "conhecimento mediatizado", o que parte do desdobramento de suas determinações internas a partir do momento em que operou a síntese, a unidade entre a subjetividade e a objetividade. Provar não consiste em tomar conceitos e elementos enquanto dados, submetendo-os, então, a uma operação que seria meramente intelectual. É o que teria feito a prova ontológica ao partir de um conceito dado, "Inbegriff", "conceito integrador ou englobante" de todas as realidades, para, assim, subsumir a existência sob a realidade 9 . Hegel extrairá a existência enquanto conceito ou propriedade da realidade. Eis o que lhe permitirá elaborar uma realidade propriamente conceitual. Note-se, ainda, que para Hegel a expressão "prova ontológica do ser-aí (Dasein) de Deus" estaria nominalmente correta, pois tratar-se-ia de um conhecimento primeiro, imediato, que se situaria na esfera do Ser, na do Dasein, e não na da Essência, na da Existência propriamente dita. Neste sentido, a tradução de "Dasein" por "Existência”, obedecendo a uma certa tradição, a uma certa comodidade, estaria conceitualmente errada. A "prova” estaria para o Dasein, para o imediato, para o Ser, assim como o "conhecimento mediatizado" estaria para o mediato, para a Essência. Ou seja, o provar mover-se-ia ainda no âmbito da fé, pois a existência não pode ser tomada por imediata, à maneira de uma realidade dada, uma realidade que estaria à mão ${ }^{10}$. Logo, a existência mesma seria considerada como não sendo provada,

\footnotetext{
${ }^{8}$ Rosenfield, Denis L. Descartes e as peripécias da razão. São Paulo, Iluminuras, 1996. Barth Karl. La preuve de l'existence de Dieu d'après Anselme de Cantorbéry, Neuchatel/Paris, Delachaux/Niestlé, 1958.
}

${ }^{9}$ Hegel. Wissenschaft der Logik. Tomo II. Frankfurt am Main, Suhrkamp Verlag, 1969, p. 126.

${ }^{10}$ Ibid., p. 127. 
pertencendo a uma condição da fé, que parte das coisas, no caso Deus, como algo já existente, dado precisamente na interioridade mesma do ato de crença, no seu jogo próprio de linguagem.

\section{A existência do Absoluto}

A pretensão filosófica de Hegel consiste em deduzir racionalmente a existência de uma Ideia, ou melhor, atribuir a existência a uma ideia, de tal maneira que esta operação seja racionalmente justificada. Sua crítica de Kant consiste em que esse não consideraria a existência como uma propriedade ou um predicado real, o que equivale a dizer que ela não seria um conceito que se aplicaria a um outro conceito de alguma coisa ${ }^{11}$. Sua démarche, portanto, não consiste, à maneira de Kant, em partir de um estado de coisas dado, admitido previamente enquanto real. Tal concepção da experiência corresponderia a do próprio empirismo, embora o enfoque kantiano seja mais refinado ao colocar as condições a priori da experiência. Na perspectiva hegeliana, tal colocação do problema não alteraria os termos de sua questão, na medida em que ele consideraria tal concepção empírica da realidade de nível a não lhe permitir uma abordagem racional de uma Ideia, a do Absoluto, que se põe em movimento e se justifica progressivamente nesta sua dicção de si. Inaugurar-se-ia um outro conceito de experiência, não mais aquele do intelecto, partindo da experiência empírica, mas o da razão que parte de uma auto-posição de si, elaborando em seu percurso suas próprias categorias, chamadas por ele de determinações, as determinações do ser, da essência e do conceito, correspondendo às Doutrinas do Ser, da Essência e do Conceito, constitutivas da Ciência da Lógica. Note-se que não estamos mais na perspectiva do Organon aristotélico, segundo o qual as categorias são aplicadas a objetos dados na experiência. A existência não seria uma categoria, na medida em que ela é a própria condição de aplicação das categorias. Ora, Hegel vai tornar a existência uma "categoria", uma determinação do pensamento, cujos desdobramentos serão, por exemplo, o "Dasein", a "Existenz" ou a "Wirklichkeit”. A realidade efetiva ela mesma será posta enquanto momento da Ideia ou do Absoluto que então se realiza. A existência seria um predicado a ser aplicado a outro conceito.

\footnotetext{
${ }^{11}$ Hegel, op. cit., Tomo I, tradução brasileira, p. 90.
} 
Graças a este deslocamento no significado mesmo do conceito de existência, tornando-a um conceito, um predicado real, a ser atribuindo a outra coisa, que Hegel estabelece as bases mesmas de sua filosofia primeira.

\section{Significações da realidade}

$\mathrm{Na}$ filosofia hegeliana, trabalha-se, habitualmente, com dois sentidos da realidade, a da realidade imediata, também dita "Realität"”, e a da realidade mediada, denominada "Wirklichkeit", traduzida por "realidade efetiva" ou "efetividade". Acontece que tal esquema conceitual, no momento de abordagem do que poderíamos também chamar de realidade dada, defronta-se com um problema importante, o de como enquadrar, por exemplo, uma realidade dada cujo atributo essencial seja, por exemplo, o de formas históricas da maldade ou de percepções préconceituais ou pré-racionais. Seria um outro tipo de realidade que não encontraria guarida nesses outros dois, pois não poderíamos considerá-lo como sendo uma realidade lógica propriamente dita, uma realidade do conceito sob a sua forma imediata. O mesmo poderia valer para formas de religiosidade fetichistas, politeístas, anímicas, não monoteístas, que não se enquadrariam, tampouco, nos conceitos de "Realität" e de "Wirklicheit". Quisera sugerir aqui uma terceira acepção de realidade em suas relações com essas. Mais precisamente, o conceito de "Dasein", no seu sentido estrito, seria uma expressão lógica da "Realität" enquanto o de "Existenz" seria próprio da "Wirklichkeit". Haveria, portanto, um processo de passagem (ou não em casos de barbárie ou incivilidade permanente) da realidade primeira em sua acepção não lógica, para a realidade do "Dasein" e desse para a do "Existenz" e da "Wirklicheit". Só poderia, no sentido preciso do termo, falar de algo existente enquanto realidade mediada no nível da "Wirklicheit". Ou seja, a "existência" seria um predicado da "Wirklicheit", ela seria um conceito, um atributo da "realidade efetiva", da realidade mediada. Não se poderia, nesta significação, considerar a existência como correspondendo a uma realidade dada. Ele seria, mais precisamente, uma qualificação desta mesma realidade, caso essa venha corresponder às suas determinações reflexivas. 


\section{"Realität”}

Hegel dá-nos uma pista muito rica destas distintas acepções da realidade no Primeiro Tomo da Ciência da Lógica, em uma observação intitulada "Realität", no capítulo dedicado ao conceito de "Qualidade"12. Nesse, ele caracteriza a realidade enquanto "Dasein", "Ser-aí", como não sendo uma simples realidade dada, que se apresentaria sob a forma, por exemplo, do "ser em si", como quando fala-se de uma coisa como sendo uma realidade que existiria mais além, independentemente de sua apropriação pela consciência. Para que uma realidade dada mereça a qualificação de "Ser-aí", ele deve reunir dentro de si, no seu interior mesmo, o "ser-em-si" e o "ser-para-outra-coisa". Nada impede que uma determinada coisa, fato ou representação, nos sejam dados sob a forma de "ser-em-si" como se fosse independente de outra coisa, como se não contivesse nenhuma alteridade interna ou externa. Nada impede tampouco que um fato se dê sob a forma do nada, da nadificação ou da destruição, não chegando a constituir-se enquanto realidade lógica do "Ser-aí". Seriam formas reais, às vezes de uma realidade aterradora, que não poderiam, hegelianamente, ser consideradas como "reais", na acepção de uma realidade lógica primeira. O que o conceito de "Ser-aí" une pode aparecer "realmente" sob a forma da separação e da fragmentação. Para que o "Ser-aí" forme- se, é-lhe necessário que seus momentos interiores, em sua separação, sejam dissolvidos e conservados em uma nova unidade. Aí sim teríamos a constituição de uma realidade lógica imediata. Mais especificamente, na medida em que o "Ser-aí" é a unidade simples e imediata do ser e do nada, sendo, pois, seus momentos, ele vem a se apresentar enquanto "Ser-aí refletido", embora não estejamos ainda na Doutrina da Essência. Haveria, portanto, uma imediatidade primeira que teria sido "aufgehoben" sob a forma de uma "imediatidade refletida". Teríamos duas acepções: a da realidade imediata (não refletida) e a da realidade imediata refletida, realidade lógica primeira. Hegel acrescenta: "o Ser-aí refletido é realidade"13.

\footnotetext{
${ }^{12}$ Ibid., p. 116-9.

${ }^{13}$ Ibid., p. 116.
} 


\section{Deus: Dasein e Existenz}

Quando discorremos sobre as "provas do ser-aí de Deus", estamos falando de uma realidade lógica de Deus, sujeita às limitações próprias da Doutrina do Ser. Logicamente, Deus já se apresenta sob a forma do conceito, embora em sua apresentação imediata primeira, seja incapaz de provar qualquer existência, porque este tipo de conhecimento mediatizado só poderia exibir-se sob a forma da "Existenz" do Absoluto, e não sob a sua forma do "Dasein". Pode igualmente ocorrer que tenhamos formas de religiosidade que não se situam sob o conceito de Deus, sob a sua forma lógica imediata, em religiões politeístas, fetichistas, anímicas e outras. Nestes casos, não se poderia, estrito senso, falar de "Ser-aí" de Deus e, menos ainda, de sua "Existência". Deus ou o Absoluto vai se constituir sob essas suas diferentes formas de dicção, em um processo que poderia ser caracterizado como de dissolução e engendramento, de supressão e conservação, elevando-se a um patamar de racionalidade superior. Assim, no momento de falarmos, na prova ontológica, do "Dasein Gottes", estaremos discorrendo sobre um Inbegriff (conceito integrador ou englobante") que se move no interior de uma realidade lógica primeira, esboçando apenas sua reflexividade, porém não ainda a realizando e desenvolvendo. Eis por que aparecerão, como seus instrumentos de prova, a justaposição de conceitos como realidade, existência e perfeição, próprios de uma atividade do entendimento em vias de se construir racionalmente. O Deus da prova ontológica seria, no seu dizer, um Deus "metafísico", pois ao ser definido como um "conceito englobante de todas as realidades" ele foi igualmente qualificado como um Deus que não contém nenhuma contradição, nenhuma de suas realidades "suprassume" as outras, excluindo de si tudo o que possa parecer negação, contradição ou imperfeição. Tal conceito tornar-se-ia um conceito vazio, que teria sido paralisado nesta atividade classificatória e de justaposição do entendimento. 


\section{Lógica e Deus}

"A lógica, desse modo, precisa ser apreendida como o sistema da razão pura, como o reino do pensamento puro. Esse reino é a verdade, como ela é sem invólucro em e para si mesma. Por causa disso se pode expressar que esse conteúdo é a apresentação de Deus, tal como Ele é em sua essência eterna antes da criação do mundo e de um espírito finito" ${ }^{15}$. A lógica, em sua acepção hegeliana, não é um instrumento do conhecimento, mas a apresentação do sistema da razão, apresentação de um nível da existência que, só assim, se revela, entendendo esta revelação sob a forma de uma revelação racional. É o pensamento que se defronta consigo em suas essencialidades puras, em suas determinações constitutivas, tendo, preliminarmente, feito a experiência da consciência em seu ser-nomundo. Uma vez de posse desta sua concepção lógico-fenomenológica, ele procura vertê-la em uma linguagem filosófica e teológica habitual, a saber, a de enunciar esse seu conceito de uma forma que seja acessível aos que não estão familiarizados com os seus conceitos e modos de pensar. Eis por que dirá que este conteúdo, lógico, é a apresentação de Deus em sua essência eterna, devendo ler-se, nesta sua formulação, a apresentação lógica de Deus em si mesmo. Ou seja, a essência eterna de Deus seria a da exposição das essencialidades puras, tal como é elaborada e exposta no sistema da razão pura, a Consciência de si da razão em si mesma. Quando acrescenta que este conteúdo lógico é anterior à criação da natureza e de um espírito finito, deve-se compreender esta formulação em um sentido específico, qual seja, o conhecimento lógico-metafísico é anterior ao conhecimento da natureza e do espírito em sua finitude. A anterioridade aqui em questão é lógica e não cronológica. Em linguagem religiosa, logo representativa, Deus aparece como anterior à criação da natureza e do espírito finito, sendo o próprio conceito de criação uma espécie de expressão acessível a pessoas não acostumadas ao linguajar propriamente filosófico. Na criação, estaríamos trabalhando com conceitos rudimentares de ser, criação ex-nihilo (nada) e vir a ser. 
48 | Veritas | Porto Alegre, v. 63, n. 1, jan-mar. 2018, p. 33-51

\section{Sumo ser ou sumo não-ser?}

A filosofia deve ter como começo algo que possa ser considerado como absoluto, onde entram em disputa diferentes acepções do ser. Aparentemente, uma escolha possível seria a de começar pelo mais absoluto, o que comumente denominamos de Deus, o Absoluto enquanto tal, ou pelo ser, onde entram, por sua vez, em disputa diferentes acepções suas. Ora, Hegel defronta-se, em sua busca pelo começo absoluto, com sua unidade de novo tipo entre o subjetivo e o objetivo, o ser e o não ser, ou na linguagem que se aproxima da Doutrina da Essência, na unidade entre o ser-diferente e o ser-não-diferente ou ainda, a identidade da identidade e da não identidade. Acidentalmente, ele observa que essas diferentes formulações poderiam ser consideradas como a mais pura definição do absoluto $^{16}$. Vejamos esta questão na linguagem da teologia ou do intelecto. Segundo a concepção tradicional de Deus, esse seria o Sumo Ser. Ora se ele é também o não ser, poderíamos qualificá-lo como o Sumo Não-Ser. O que pode bem significar então essa introdução do não ser na interioridade mesma de Deus? Claro que Hegel observa que se trata da unidade do ser e do não-ser, procurando, desta maneira, evitar este escolho. Contudo, há um claro rompimento com a teologia tradicional. Poderíamos fazer o mesmo tipo de colocação caracterizando Deus como a Suma identidade ou a Suma não-identidade, voltando-se novamente para a unidade entre ambos, pondo o Ser absoluto assim entendido em uma posição de novo tipo.

\section{Abgrund e Grund}

Na perspectiva da razão finita, que não empreendeu ainda o seu processo de determinação de si, o que a caracterizaria enquanto razão infinita, uma razão ainda confrontada com um outro que a supera e ultrapassa, Deus aparece como sendo esse algo essencialmente outro. Um outro que se mantém sempre para além dela, constituindo uma espécie de Abismo (Abgrund), diante do qual ela recua ${ }^{17}$. Apesar da linguagem mística aqui presente, tal caracterização da relação da razão finita com Deus ou o

\footnotetext{
${ }^{16}$ Ibid., p. 76 .

${ }^{17}$ Hegel, Wissenschaft.., op. cit., p. 128.
} 
Absoluto é a que define o conceito de Deus como "absconditus”, escondido, inalcançável, incognoscível. Não há aqui mediação, mas uma parada frente a algo intransponível. A razão defronta-se com seu limite, crê em algo imediato que a ultrapassa completamente. $\mathrm{O}$ ato de fé é, neste sentido, um ato de submissão ao totalmente outro que a engloba enquanto tal, um conceito englobante que tudo abarca e domina. O empreendimento hegeliano, porém, consistirá em fazer deste "Abgrund" um "Grund", do "abismo" um "fundamento", do imediato uma etapa da mediação, mediante a qual o ser puro chega a si mesmo, o Absoluto apresentando-se enquanto condição e resultado deste processo de mediação. O Abgrund enquanto fundamento negativo tornar-se-á a essência apresentando-se como mediação do ser, a essência engendrando-se em sua reflexão, em sua negatividade, como fundamento positivo ${ }^{18}$. O Abgrund aparece, então, verdadeiramente enquanto momento do Grund. A linguagem mística ou religiosa dá lugar à linguagem propriamente filosófica. Deus é substituído pelo Absoluto, a Essência última de todas as coisas pelo movimento reflexionante da essência, na acepção hegeliana da Doutrina da Essência.

\section{A interioridade do Absoluto}

Hegel tem a pretensão de expor racionalmente a interioridade mesma do Absoluto, prescindido completamente de qualquer ato de fé. Deus pode ser apreendido pela razão, não mais funcionando como um estado de coisas dado que seria oferecido ao intelecto, que sobre ele se debruça para conhecê-lo. A razão torna-se completamente autônoma. Com tal propósito, deverá, a partir de si mesma, expor gradativamente suas determinações, começando pelas mais simples, como o ser, o nada e o devir, até as mais complexas do conceito, passando pelas da essência, que são as da reflexão, "movimento de nada a nada e de volta a si mesmo" e, em particular, a do "zugrunde(zu Grunde) gehen, o abismamento que é um encontro no fundamento, vindo a por, a instaurar, um novo conceito de existência. Estaríamos diante da própria dialética explicitada em suas determinações constitutivas, pois, retomando uma formulação da Filosofia do Direito, ela seria nada mais do que o seu processo de dissolução e de

\footnotetext{
${ }^{18}$ Ibid., p. 128.
} 
engendramento de si mesma ${ }^{19}$. Como é possível, porém, partindo de nosso conceito corrente de Deus, considerá-lo enquanto submetido a um processo de auto-negatividade, fazendo com que venha a fazer a experiência de sua negatividade radical de si mesmo? Tratar-se-ia de um Deus que faria - e poderia fazê-lo novamente - a experiência de ir ao abismo, de vivenciar o seu próprio abismamento. Em todo caso, tal concepção é em todo dissonante em relação a nossa noção de um Sumo Ser, em que residiria a suma perfeição. Como poderíamos ter um Deus sumamente perfeito que faria em si a experiência do abismo e, em outra linguagem, a da carência, a da falta e a da negatividade?

\section{Questão originária}

Poder-se-ia colocar uma questão suscetível de ser denominada de originária. Deus viveria a experiência do "Abismo/Fundamento" em si mesmo ou em sua relação com a razão finita que o enuncia por intermédio da Ciência da Lógica, porém levando em consideração os diferentes "abismos" da experiência humana no decurso da história, sob as formas da maldade, das perseguições religiosas ou étnicas, da miséria e das guerras? Do ponto de vista, digamos textual, trata-se da obra de um filósofo que chega a este tipo de concepção, embora, em sua perspectiva, ele o considere como a verdadeira exposição da coisa mesma, uma espécie de revelação filosófica que inauguraria um novo pensar humano em geral e, em particular, um pensar racional do Absoluto. Deus conhecer-se-ia em sua verdadeira natureza graças a essa enunciação filosófica, a esta dicção da razão de si mesma. Neste sentido, seria o Deus desta forma de interlocução filosófica. Ou melhor, seria o Deus da Condição Humana. Deus ver-se-ia desta forma graças a uma Ideia racional, que, previamente, teria feito a experiência da história, do vir a ser humano em suas experiências mais cruciais de radical separação de si e de reunificação consigo, abrindo-se, subsequentemente, a novas diferenciações. O homem, em seu vir a ser, teve a experiência do abismo, da perda e, mesmo, da desesperança e do desamparo, antes de ver-se diferentemente neste mesmo percurso de si. Graças à elaboração filosófica desta experiência

\footnotetext{
${ }^{19}$ Hegel. Princípios da Filosofia do Direito. §§ 31-2. Tradução de Paulo Meneses, Agemir Bavaresco, Alfredo de Oliveira Moraes, Danilo Vaz-Curado R. M. Costa, Greice Ane Barbieri, Paulo Roberto Konzen. Belo Horizonte, Edições Unisinos/Loyola, 2016.
} 
originária da condição humana, pode o filósofo vir a conhecer-se mediante um outro conceito de Deus. Seria, neste sentido, tentado a dizer que Hegel teria elaborando um novo enfoque, lógico-metafísico, do conceito leibniziano de Teodiceia. Ou seja, a questão com a qual teria Hegel se confrontado foi a de uma Teodiceia logicamente concebida, levando em consideração o conjunto da história humana em seu processo progressivo de vir a ser, de consciência racional de si.

\section{Referências}

Bíblia Sagrada. Salmo 145 - Salmo de David. Tradução de João Ferreira de Almeida, São Paulo, Sociedade Bíblica do Brasil, 1993.

Hegel. Ciência da Lógica. Tomo I. Prefácio a Primeira edição. Tradução de Christian Iber, Marloren Miranda e Federico Orsini. Petrópolis, Vozes, 2016.

Hegel. Wissenschaft der Logik. Tomo II. Frankfurt am Main, Suhrkamp Verlag, 1969

Hegel. Princípios da Filosofia do Direito. §§ 31-2. Tradução de Paulo Meneses, Agemir Bavaresco, Alfredo de Oliveira Moraes, Danilo Vaz-Curado R. M. Costa, Greice Ane Barbieri, Paulo Roberto Konzen. Belo Horizonte, Edições Unisinos/Loyola, 2016.

Hegel, G. W. F. Science de la logique. Tomo I. Primeira edição de 1812. Traduction, présentation et notes par Pierre-Jean Labarrière et Gwendoline Jarczik. Paris, Aubier, 1972.

Heschel, Abraham Joshua. God in Search of Man. New York, Farrar, Straus and Giroux, 1976.

Rosenfield, Denis L. Descartes e as peripécias da razão. São Paulo, Iluminuras, 1996. Barth Karl. La preuve de l'existence de Dieu d'après Anselme de Cantorbéry, Neuchatel/Paris, Delachaux/Niestlé, 1958.

Santo Anselmo. Proslogion. In: L'oeuvre de S. Anselme de Cantorbery. Tomo I. Introduction, traduction et notes par Mchel Corbin, s.j. Paris, Cerf, 1986. Tradução de Angelo Ricci. São Paulo, Abril/Nova Cultural, 1988.

\section{Endereço postal:}

UFRGS - IFCH - Campus do Vale

Av. Bento Gonçalves, 9500 - Prédio 43311

Porto Alegre, RS 91509-900

Data de recebimento: 11/01/2018

Data de aceite: 10/03/2018 